\title{
Empowering Employees for Quality of Service;The Role of Employee Empowerment on Quality of Service: In Case of Commercial Bank of Ethiopia, Ambo Branch
}

\author{
Bekan Serbessa Waktola \\ Ambo University, College of Business and Economics, Department of Management
}

\begin{abstract}
The study was about the role of Employee empowerment to quality of service in case of Commercial Bank of Ethiopia, Ambo Branch. This study focused on identifying and clarifying the relationship between employee empowerment and quality of service. The deals the concepts of such as Criteria for employees empowering, training and Employee, Job and Autonomy, manager and Employee, share important Goal and direction, empowered employee with decision making and suggestion and its relation with quality of service .The study adopted a descriptive research design. The population of the study was 53 employees' of Commercial Bank of Ethiopia from these 48 employees would be fully participated in the study. Census sampling was done. Data collection was by using questionnaires which are filled by employee and manager interview questions. The questionnaire was administered by the researchers. The completed questionnaires were edited for completeness. The data was interpreted using descriptive statistics through frequencies, percentages analysis. Based on the result of the findings, employee empowerment has positive and significant impact on service quality. The employees are highly empowered to deliver quality services to customers. This is evident in the assignment of particular employees to specified customers, to ensure they maintain a direct personal relationship with them.
\end{abstract}

Keywords: Empowerment, Quality of Service

DOI: $10.7176 / \mathrm{EJBM} / 11-31-03$

Publication date: November $30^{\text {th }} 2019$

\section{INTRODUCTION}

Employee empowerment is very crucial for the survival and success of an organization, and it gives employees a sense of feelings that they are the core assets to the organizational success, creates commitment and a sense of belonging, builds trust, promotes effective communication, and increases organizational effectiveness and employee wellbeing. Ongari (2009), Brown and Harvey (2006) define employee empowerment as a process of giving staffs or employees the authority or power to make decisions about their own job. Karakoc and Yilmaz (2009) views employee empowerment as one of the most effective means of allowing employees at every level to utilize their creative thinking and abilities to improve the quality of their work and the performance of the organization.

Employees in service organization and particularly those who have frequent contact with the customer usually service representative of both the organization and their product or service to the customer at contact point. Employees who are empowered in organization can either partly a positive or negative picture to the customer. Considering that a satisfied customer and employee are important value to the organization; therefore it becomes the duty of management to put in a place a system that would ultimately generate either satisfaction or dissatisfaction from their customer and employees, since the employees have a major role to play in determining whether a customer would enjoy the experience or turn to their competitors for better solution. Employees in a service organization and particularly in banks those who have frequent contacts with the customer usually viewed as an ambassador of both the organization and their products or services to the customer over the counter. The quality of the service and the satisfaction the customer may derive will be an assessment of the entire service experience. Organizations that are committed to the ongoing growth of their employees recognize employee empowerment as one of their most important strategic methods to motivate employees. Employee empowerment is also a key strategy to enable people who have the need, the answers, and the knowledge, to make decisions about how to best serve customers.

In a service organization quality of service and customer satisfaction is very determinants. Customer Satisfaction is when the outcome of the service matches the expectations of the service. Service Quality is one of those factors that contribute to customer satisfaction, in other words a component of customer satisfaction measure. The level of customer satisfaction is the result of the customers comparison of the service quality expected in a given service encounter, with the perceived service quality. Customer satisfaction and quality of service is essential instrument for the success of service organization Zeithaml et al (2006)

According to Vecchio (2000), employee empowerment refers to a set of motivational techniques that are designed to improve employee performance through an increased level of employee participation and selfdetermination. Similarly it is defined as organizational arrangements that give employees more autonomy, 
discretion and decision-making responsibility (Buchanan \& Huczynski 2004). In order words, lower level employees are given more power, responsibility and freedom to make choices about how to perform their job and how to deal with any of their work-related problem, hence influence organizational outcomes.

Employee empowerment has significant role in any service delvering organization by raise level of service of employee effectively. Most study has been conducted to investigate employee empowerment aspect of service delivering organization both locally and internationally among study done outside Ethiopia.

The study had both general and specific objectives.

The General objective of the study was to investigate Role employee empowerment on quality of service in the commercial bank of Ethiopia. The specific objectives of the study are:

- To explore how employee empowerment looks like in Commercial bank of the Ambo branch

- To know the relationship between employee empowerment and quality of service in Commercial bank of the Ambo

- To examine how employee empowerment affects the quality of service Commercial bank of the Ambo The study answered the following research questions

- How employee empowerment looks like in CBE Ambo branch

- What is the relationship between employee empowerment and quality of service in CBE ambo branch

- How employee empowerment affects quality of service in commercial bank of Ethiopia, Ambo branch?

\section{II, LITERATURE REVIEW}

Employee empowerment is a strategy and philosophy that enables employees to make decisions about their jobs and helps employees own their work and take responsibility for their results as well as serve customers at the level of the organization where the customer interface exists. It is one of the keys to implementing profitability improvement and other organizational change and maintaining continuous improvement (Lashley, 2000). Employee empowerment has become a buzzword and a recent management trend in both the public and private sectors (Pitts, 2005). Employee empowerment has received a wide recognition as an important subject in management circles mainly because it is seen as one of the fundamental elements of managerial and organizational effectiveness that increases when power and control are shared in organizations (Ergeneli et al., 2007). Thus employee empowerment has been hailed as a management technique which can be applied universally across all organizations as a means of dealing with modern global business (Demitriades, 2005). Generally employee empowerment comprises of innovative approaches in working with people and a shift of power from the top management control to lower level management of the organization (Tzafrir,2004). Osborne and Plastrik (2000) argue that empowering employees is not only about cheering them on or being nicer to them. It is about giving them real power. To do that, bureaucratic controls that keep workers in their place must be dismantled .According to Osborne and Plastrik (2000), the process targets several control mechanisms which include highly centralized organizational structures, excessive layers of management, rigid job classifications and functional "silos, written rules, And inflexible labor-management contracts and grievance processes". Therefore, empowerment is not a product of any structure or system, but it is process, which is ongoing, dynamic, and fluctuating (Ongori and Shunda, 2008).

Employee empowerment program to be successful in an organization, management must put in place a structure in the system to support the whole process (Bogler andSomech, 2004). It is recommendable that empowerment process should take place in an environment where it is allowed, nurtured and promoted by management and employees (Ongori and Shunda, 2008).

Employee empowerment means the transfer of power to other. Brown and Harvey (2006) define employee empowerment as a process of giving staffs or employees the authority or power to make decisions about their own job. According to Gill (2011), employee empowerment refers to the meaningful job of employees, their feelings of competence, autonomy, and contribution to the decision making or applications of leadership. The employee empowerment concept actually certifies the employees with necessary power to employ plan and judgment in their work, participate in their work related decision-making, and authorizes them to respond quickly to the needs and concerns of the customers, Employee empowerment, and views employee empowerment as a process of transferring power from the employer to the employees. This transformation of power benefits organizations in many forms. Ghosh (2013) argues employee empowerment merges from four different perspectives: social, psychological, growth and organizational. Kahreh et al. (2011) describes employee empowerment from psychological and employment climate perspectives. Demirci and Erbas (2010) reason that empowerment formulated (Fig. 1) by the combination of four components: power, information, knowledge and rewards. Power refers to the ability of getting things completed. Power is concerned with the autonomy, delegation and authority given to the employees. Information compasses the employees' access to the data related to the organizational objectives and strategy, and active engagement in the process of decision-making (Vacharakiat2008). Information also includes clarification of individual role and feedback obtained from manager, subordinates and peers. Sharing of knowledge is a group process where employees share relevant information, knowledge and ideas regarding their 
work (Yasothai et al. 2015). Reward indicates the monetary or non-monetary benefits that an employee receives, which is considered an effective tool to increase employee motivation (Yasothai et al.2015)

\begin{tabular}{|l|l|l|l|}
\hline \multicolumn{4}{|c|}{ Empowerment $=$} \\
\hline Power $\times$ Information $\times$ Knowledge $\times$ Rewards & Rewards \\
\hline \multicolumn{1}{|c|}{ Power } & Information & Training & Compensation \\
\hline Autonomy & Feedback & Counseling & Career planning \\
\hline Authority & Role clarification & Appraisal & Job enrichment \\
\hline Delegation & Motivation &
\end{tabular}

Fig. 1. Instruments of empowerment

(source: Demirci, Erbas 2010)

2.3.1 Benefits of employee empowerment

The obvious benefit was an increase quality along with the production in warranty costs. Other benefits of empowerment also evolved in to believing excuse for implementation of principles.

Empowerment can raise the level of service of employees effectively, mobilize the enthusiasm of employees motivates employees to provide customers with service quality and customer satisfaction. Many enterprises found that they have to empower employees.

Some commonly suppose that employee empowerment leads to an increased commitment to the business' success and those empowered employees will use their full potential and expertise in order to reach the organization's overall goals (Lashley, 2001).

Empowered employees Leaders who empower employees enable them and their organizations to deal more successfully with market turbulence and unforeseen demands of the future. In the service industry, empowerment is particularly important.

\section{The Relationship Between Service Quality And Employee Empowerment}

In response to these inquiries above, the theoretical and empirical evidence suggests certain benefits that employee empowerment can bring to service organization in general and to bank service organizations in particular. First of all, empowered staff are able to provide guests with prompt responses to service requests, quicker solutions to service failures, bend the rules to please customers, use creativity to please guests, which helps enhance service quality and customer satisfaction (Ro \& Chen 2011; Chow et al. 2006).

The relationship employee empowerment with quality of service and customer satisfaction

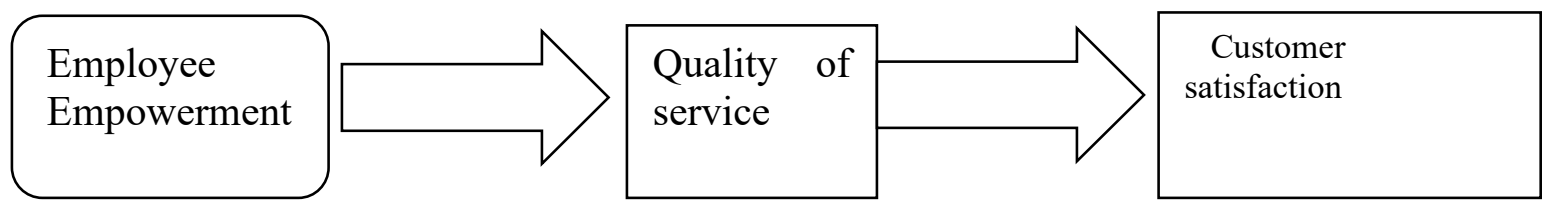

\section{III: RESEARCH METHODOLOGY}

Research Design, Data Source, Type and Data Collection Method

The study used descriptive research design. The quantitative and qualitative research approach has been applied to attain the objective of the study. To undertake this study primary and secondary source of data has been collected. The primary data has been collected through interview and distributing questionnaires to employee of the bank. Questionnaire was conducted based on the research problem identified and distributed to all employees of the bank. Open and close ended questionnaires have been prepared and all questionnaires were prepared in relation to the objectives of the study. And interview was conducted with the manager of the organization.

Since the numbers of employees in the organization was manageable, the researcher used census survey to conduct the study. The aim of choosing these techniques is in order to make the study more reliable and representative.

The target populations for this study were 53 employees of Commercial bank of Ethiopia, Ambo branch which is found in Ambo town. After collecting the necessary data from the respondents, the data has have been processed in accordance with the objectives of the study then the data was analyzed by statistical tools like; percentage, table and then it has descriptive explanation under each percentage and table

\section{DATA ANALYSIS AND Discussion}

Demographic Profile of Respondents

1. Sex distribution of respondents: the majority of respondent were male (85.4\%) and the remaining $(14.6 \%)$ were female.

2. Age distribution of the respondents: less than 25 years contain $8.3 \%$ respondents, Between $25-35$ years contain of $85.4 \%$ respondents, were aged between $36-50$ years contain $6.3 \%$ respondents. This show the majority of the 
bank employee are middle age person.

3. Educational level of respondents: Based on education back ground the majority of respondent are $60.4 \%$ (BA degree)respondent and diploma hold $6.3 \%$ and also MA degree hold $33.3 \%$ of respondent so this implies that that the employee are competent to carry out their responsibility or duties. BA Degree and MA degree employees were more required by the $\mathrm{CBE}$ in the ambo branch than diploma.

4. Work Experience: The results indicated that most of the respondents had worked between 4 to 9 years $(75 \%)$. This was followed by $22.9 \%$ with below 4 years work experience, $2.1 \%$ between 10 to 15 years, work experience. This indicates that majority of the respondents are relatively well experienced.

Table 1 : perceived Culture of Empowering in the organization

\begin{tabular}{lll}
\hline Option & Frequency & Percentage \\
\hline Yes & 47 & $97.9 \%$ \\
No & 1 & $2.1 \%$ \\
Total & 48 & $100 \%$ \\
\hline
\end{tabular}

Source: Survey, 2019

Employees perception on Culture of Empowering in $97.9 \%$ of employees respondent that, the bank is good enough in empowering its employees and the remaining $2.1 \%$ of employees replied that the bank did not empower its employees(see table 1).From this the it conclude that the commercial bank of Ethiopia in ambo branch has the culture of it's empower employee Figure 1 Criteria for employees empowering

\section{criteria of delegatiion in the bank}

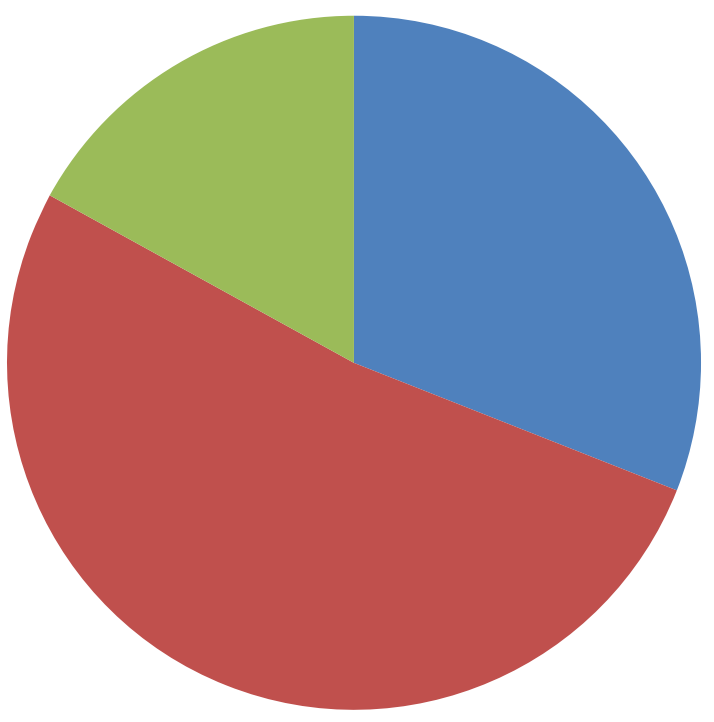

level of education

n experience

year of service

As calculated in the above figure shows $52.1 \%$ of the employees stated that employee empowering depends on experience at the employees. And $31.3 \%$ of the employees expressed that the empowerment of employee depend on the level of education. The remaining $16.6 \%$ of the employees suggested that employee empowering depend on year of serving the organization.

Based on the opinion of the employees, the researchers concluded that the bank in ambo branch empower its employees depending on the experience at the employees

Table 2 Training Employees for Empowerment

\begin{tabular}{lll}
\hline Option & Frequency & Percentage \\
\hline Yes & 42 & $87.5 \%$ \\
No & 6 & $12.5 \%$ \\
Total & 48 & $100 \%$ \\
\hline
\end{tabular}

Source: Survey, 2019

Majority of respondents $(87.5 \%)$ of employees of the organization receive training in area of work since joined in the bank. The rest respondent $12.5 \%$ of employee does not receive training in area of work since joined into bank(see table 2)

From this we can conclude that majority of the employee who are working in the organization had got trainings that can help them to empower on their work 
Figure 2 Job and Autonomy

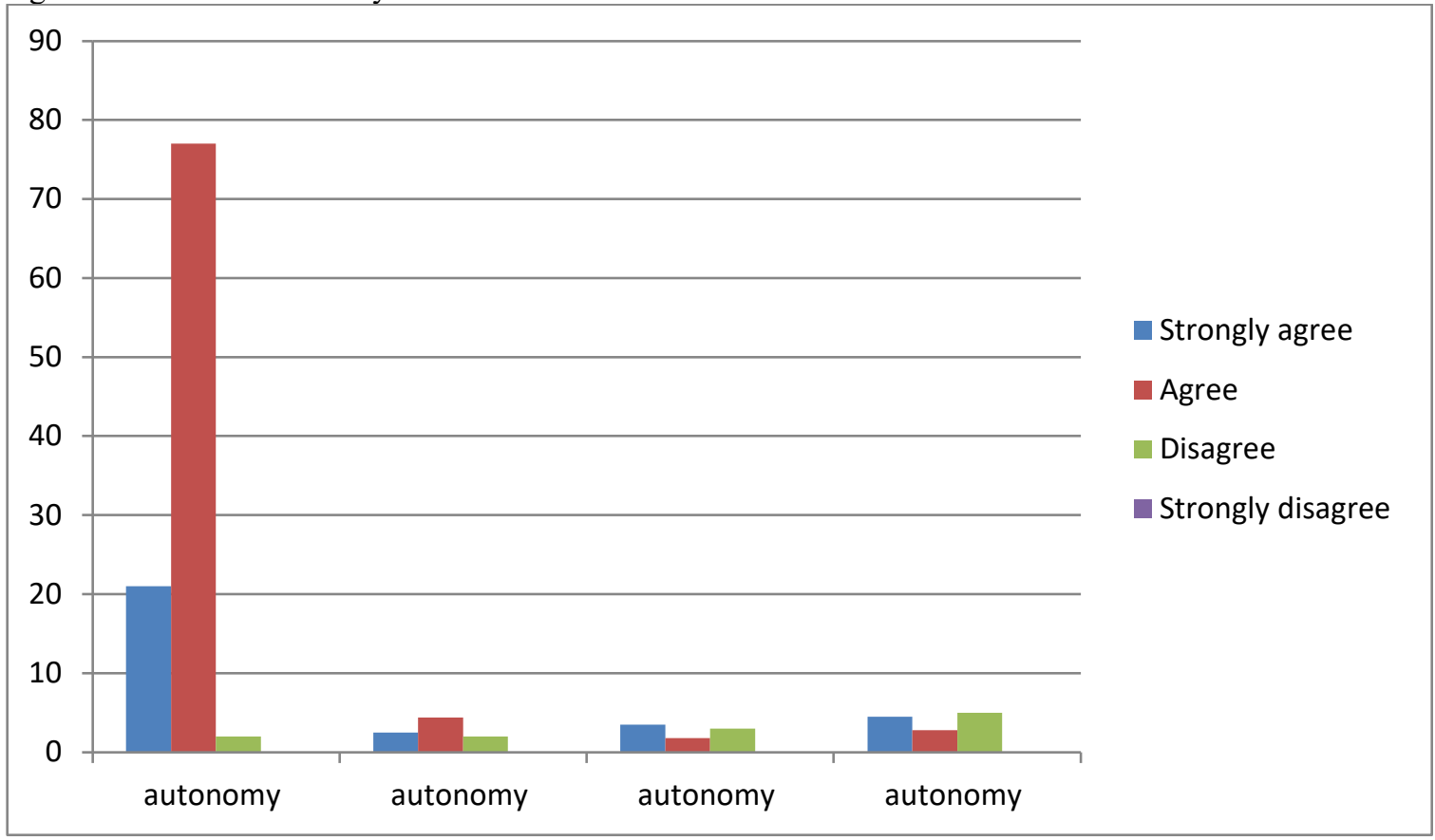

The above figure show that $77.1 \%$ of employees of the agree with autonomy on in the job. And $20.8 \%$ of employees was strongly agree and also $2.1 \%$ of employee Disagree. From the above table it can be seen that there were no employees who strongly disagree autonomy on in the job. Based on the finding of the study, it is clearly depicted that the employees in the bank had a good autonomy in their work. Gronroos, (2001) Stated that the autonomy of the employee is necessary which supports the employee to perform their job in a good manner that can go a long way to making a difference in the organization. Buchanan \& Huczynski (2004) also asserts that Employee empowerment in the organizational arrangements give employees more autonomy, discretion and decision-making responsibility. Therefore the findings of this study go along with the pervious researchers.

Table 3: Extent of Manager and Employees Relation

\begin{tabular}{lll}
\hline & \multicolumn{2}{c}{ Respondents } \\
\hline Extent & Frequency & Percentage \\
Always & 7 & $14.6 \%$ \\
Usually & 10 & $20.8 \%$ \\
Some times & 16 & $33.3 \%$ \\
Rarely & 8 & $16.7 \%$ \\
Never & 7 & $14.6 \%$ \\
Total & 48 & $100 \%$ \\
\hline
\end{tabular}

Source: Survey, 2019

Based on the information above the researchers conclude that the manager has delegated his employees. While employees are given more power, responsibility and freedom to make choices about how to perform their job and how to deal with any of their work-related problem, hence influence organizational outcomes. The core of empowerment is to release the knowledge, experience, and motivational power that are already in people but are greatly underutilized (Blanchard, Carlos \& Randolph 1999). Hence the findings of this study go along with the finding of the previous study

Table 4: Extent of share important goal and direction

\begin{tabular}{lll}
\hline \multicolumn{2}{c}{ Respondents } \\
\hline Extent & Frequency & Percentage \\
Strongly agree & 21 & $43.7 \%$ \\
Agree & 27 & $56.3 \%$ \\
Disagree & - & - \\
Strongly disagree & - & -- \\
Total & 48 & $100 \%$ \\
\hline
\end{tabular}

Source: Survey, 2019

The above table explained that almost all respondent $60 \%$ replied that agreed with Manager share the important goals and direction And $40 \%$ of employees was strongly agree ,From the above table it can be seen 
that there were no employees who disagree and strongly disagree manager share the important goals and direction for them .Based on above information the researchers concluded that manager of commercial bank of Ethiopia in Ambo branch has share important goals and direction to the employees.Managers should share the most important goals and direction for their groups. Where possible, managers can either make progress on goals measurable and observable, or ascertain that they have shared their picture of a positive outcome with the people responsible for accomplishing the results Heathfield (2006). Therefore the findings of this study go along with the finding of the previous study

Employees need to be clear about why empowerment is occurring and how it will meet the purpose and goals of the organization. They should have substantial input into how the organization will proceed with employee empowerment. And they must have some time and many opportunities to adapt. Heathfield (2006). Therefore the findings of this study go along with the finding of the previous study. The researchers conclude that the manager of commercial bank of Ethiopia in ambo branch had good relation with employee.

Table 5: Relationship between employee Empowerment and Service quality

\begin{tabular}{lll}
\hline Extent & Frequency & Percentage \\
\hline Strongly agree & 28 & $58.3 \%$ \\
Agree & 19 & $39.6 \%$ \\
Disagree & 1 & $2.1 \%$ \\
Strongly disagree & - & - \\
Total & 48 & $100 \%$ \\
\hline
\end{tabular}

Source: survey, 2011

As the table result shows that the majority respondents $58.3 \%$ of employees of commercial bank of Ethiopia in ambo branch strongly agree with empowering employees have positive relationship with service quality and $39.6 \%$ of employees were agreed and also $2.1 \%$ of employee Disagree. From the above table it can be seen that there were no employees who strongly disagree positively related of employee empowering and service quality. The researcher concludes that, there is strong relationship between employee empowerment and service quality. Table 6: Empowered employee with decision making and suggestion

\begin{tabular}{lll}
\hline & \multicolumn{1}{c}{ Respondents } \\
\hline Extent & Frequency & Percentage \\
Strongly agree & 19 & $39.6 \%$ \\
Agree & 20 & $41.6 \%$ \\
Disagree & 7 & $14.6 \%$ \\
Strongly disagree & 2 & $4.2 \%$ \\
Total & 48 & $100 \%$ \\
\hline
\end{tabular}

Source: Survey, 2019

According to $39.6 \%$ respondent of , employees of the organization strongly agree with Empowered employee make quick decision and suggestion that improve quick service delivery in their place of operation and save a lot of money and time in the organization and $41.6 \%$ of employees was agreed and also $14.6 \%$ of employee Disagree. The rest respondent $4.2 \%$ of employee strongly disagree Empowered employee make quick decision and suggestion that improve quick service delivery in their place of operation and save a lot of money and time in the organization (see table 6).The researchers conclude that, Empowered employee make quick decision and suggestion that improve quickly service delivery in their place of operation and save a lot of money and time in the organization. Empowered employees can make decisions and suggestion that will down the line to improve service and support, saving money, time and disputes between companies and their customers sisterly (1998). Therefore the findings of this study go along with the finding of the previous study.

Table 7: Relationship between empowerment and Employee

\begin{tabular}{lll}
\hline Extent & Count & Percentage \\
\hline Strongly agree & 20 & $41.6 \%$ \\
Agree & 24 & $50 \%$ \\
Disagree & 2 & $4.2 \%$ \\
Strongly disagree & 2 & $4.2 \%$ \\
Total & 48 & $100 \%$ \\
\hline
\end{tabular}

Source: survey, 2019

$50 \%$ of employees of the organization agreed with Empowerment leads to employee long term commitment toward achieving the organizational objective and $41.6 \%$ of employees was strongly agree and also $4.2 \%$ of employee Disagree. The rest respondent $4.2 \%$ of employee strongly disagree Empowerment leads to employee long term commitment toward achieving the organizational objective (see above table). Some commonly suppose that employee empowerment leads to an increased commitment to the business' success and those empowered employees will use their full potential and expertise in order to reach the organization's overall goals (Lashley, 
2001).Generally Empowerment leads to employee long term commitment toward achieving the organizational objective. Therefore the findings of this study go along with the finding of the previous study.

Table 8: Information and Employee relationship

\begin{tabular}{lll}
\hline Extent & Employee & Percentage \\
\hline Strongly agree & 16 & $33.3 \%$ \\
Agree & 29 & $60.4 \%$ \\
Disagree & 2 & $4.2 \%$ \\
Strongly disagree & 1 & $2.1 \%$ \\
Total & 48 & $100 \%$ \\
\hline Source: & &
\end{tabular}

Source: survey, 2019

As above table 8 show almost of respondent $60.4 \%$ of employees of the organization agreed with Necessary information is readily availed to all concerned employee in good time to enable them make thoughtful decision and $33.3 \%$ of employees was strongly agree and also $4.2 \%$ of employee Disagree. The rest respondent $2.1 \%$ of employee strongly disagree Necessary information is readily availed to all concerned employee in good time to enable them make thoughtful decision. No one can make good decisions without good information. An organization committed to empowering employees must ensure that they have access to all the relevant information. There must be a well thought-out and effective way of moving information around the organization. Managers should make certain that they have given people, or made sure that the people have access to, all of the information they need to make thoughtful decisions Delegate authority and impact opportunities, not just more work Heathfield (2006) therefore the findings of this study go along with the finding of the previous study.

From the finding of these researchers we can conclude that in commercial bank of Ethiopia in ambo brunch necessary information is readily availed to all concerned employee in a good time to make decision Therefore the findings of this study go along with the finding of the previous study Heathfield (2006)

Table 9: Relationship between Employee empowerment and decision making

\begin{tabular}{lll}
\hline Extent & Count & Percentage \\
\hline Strongly agree & 18 & $37.5 \%$ \\
Agree & 26 & $54.2 \%$ \\
Disagree & 3 & $6.2 \%$ \\
Strongly disagree & 1 & $2.1 \%$ \\
Total & 48 & $100 \%$ \\
\hline Source: & &
\end{tabular}

Source: Survey, 2019

As above table 9 show almost of respondent 54.2\% of employees of the organization agreed with Employee empowerment leads to more flexibility and faster decision making and 37.5\% of employees was strongly agree and also $6.2 \%$ of employee Disagree. The rest respondent $2.1 \%$ of employee strongly disagree Employee empowerment leads to more flexibility and faster decision making .Based on above information the researchers conclude that Employee empowerment more important to make more flexibility and faster decision making

\section{Conclusions}

In this study, the relationship between employee empowerment and service quality was examined. Based on the result of the findings, employee empowerment has positive and significant impact on service quality. This research confirms that employee empowerment improves quality of service. The employees are highly empowered to deliver quality services to customers. This is evident in the assignment of particular employees to specified customers, to ensure they maintain a direct personal relationship with them. From the responses, when employs are unable to handle a given situation or when they are not knowledgeable about something they consult their fellow employees. They can also consult the bank manager or the general manager. The bank uses employee empowerment as a tool to enable their employees' deliver the right kind of service quality the bank stands for. Employees are given a high degree of autonomy, regarding decisions affecting customer service. These empowered employees are highly motivated to provide greater service and enable them to 'own' the job, exercise freedom while controlling the service process and individually respond to customers need in an excellent fashion Employees need to be clear about why empowerment is occurring and how it will meet the purpose and goals of the organization. They should have substantial input into how the organization will proceed with employee empowerment. And they must have some time and many opportunities to adapt. In response to these inquiries above, the theoretical and empirical evidence suggests certain benefits that employee empowerment can bring quality service organization in general and to bank service organizations in particular.

\section{REFERENCES}

Brown, D. R.; Harvey, D. 2006. An experimental approach to organizational development.7thed..

Chen, J. C. \& Silverthorne, C (2008). The Impact of Locus of Control on Job Stress, Job Performance And Job 
Satisfaction In Taiwan. Leadership \& Organization Development Journal,

Chow, I. H., Lo, T. W.,Sha, Z.and Hong, J., 2006. The impact of developmental experience, empowerment, and organizational support on catering service staff performance.

Christian Grönroos, (2001) Service management and marketing: a customer relationship management approach. England: John Wiley and sons limited. 2nd edition.

Demitriades, S. Z. (2004), "Employee Empowerment in the Greek Context" International Journal of Manpower,

Demirci, M. K.; Erbas, A.( 2010). Employee empowerment and its effect on organizational performance, in $2 n d$ International Symposium on Sustainable Development,

Ergeneli, A., Saglam, G. and Metin, S. (2007), "Psychological empowerment and its Relationship to Trust in Immediate Managers" Journal of Business Research,

Greasley, K., Bryman, A., Dainty, A., Price, A. and Soetanto, R. (2005), “Employee Empowerment” Employee Relations,

Gill, R. 2011. Theory and practice of leadership. 2nd ed.

Ghosh, A. K(. 2013) Employee empowerment: a strategic tool to obtain sustainable competitive advantage, InternationalJournal of Management

Gazzoli, G., Hancer, M. and Park, Y., 2010.The role and effect of job satisfaction and empowerment on customers' perception of service quality,

Hoffman, K.D. , Bateson, J.E.G. (2002). Essentials of Services Marketing: Concepts Strategies, and Cases, 2nd ed.

Heathfield M. S. (2006), “Top Ten Principles of Employee Empowerment”,

Hocutt, M.; Stone,(1998). The impact of employee empowerment on the quality of a service recovery effort, Journal of Quality Management

Kotler, P;Keller, K. L. 2006.Marketing management.14th Ed.

Kahreh,M. S; Ahmadi, H. Hashemi A. 2011. Achieving competitive advantage through empowering employees: an empirical study, Far East Journal of Psychology and Business

Karakoc, N; Yilmaz, A. K. 2009. Employee empowerment and differentiation in companies: a literature review and research agenda

Looy, B.V., Gemmel, P., \& Van Dierdonck, R. (2003). Service Management : An Integrated Approach. (2nd ed.).

Lloyd, P., Braithwaite, J. and Southern, G. (2006), "Empowerment and the Performance of Health Services", Journal of Management Medicine,

Lashley, C. 2001. Empowerment: HR strategies for service excellence. Elsevier But-Tamworth Heinemann: Oxford.

Ongori, H. and Shunda, J. P. W. (2008), “Managing Behind the Scenes: Employee Empowerment”, International Journal of Applied Economics and Finance,

Osborne, D. and Plastrik, P. (2000), The Reinvention's Field book,

Ongori, H. 2009. Managing behind the scenes: a view point on employee empowerment, African Journal of Business Management

Petty A (2005) meta analysis of the relationship between individual job satisfaction and individual performance, Academy of Management Review

Ro, H., Chen, P., 2011. Empowerment in hospitality organizations: Customer orientation and organizational support. International Journal of Hospitality Management,

Sureshchandar, G.S., Rajendran, C. and Anantharaman R.N., 2002. The relationship between management's perception of total quality service and customer perceptions of service quality.

Tzafrir, S. S., Havel, H. G., Yehuda, B. and Dolan, S. L. (2004), "The Consequences of Emerging HRM Practices, Trust in their Managers", Journal of Personnel Review,

Vecchio, R., 2000. Organizational Behavior: Core Concepts.4th Ed.

WWW.Combank eth.com).

Yasothai, R.; Jauhar, J.; Bashawir, A. G. 2015. A study on the impact of employee performance: the mediating role of appraisal, International Journal of Liberal Arts and Social Science

Zeithmal, V.A.,Parasuraman, A. \& Malhotra, A. (2000). Service quality delivery through websites: a critical review of extant knowledge, Journal of the Academy of Marketing Science,

Zeithaml, V.A, Mary Jo, B \& Dwayne D.G (2006).Service marketing; integrating customer focus across the firm. ( 4th ed.). 